\title{
The Dynamic of Humility and Wisdom: The Syrophoenician Woman and Jesus in Mark 7:24-31a $\mathbf{a}^{1}$
}

\author{
Christopher E. Alt ${ }^{*}$ \\ Boston College School of Theology \& Ministry
}

Although Jesus' encounter with the Syrophoenician woman in Mark 7:24-31a is often presented as an example of the woman's faith, the exchange between the woman and Jesus also offers readers insights into living out the virtues of humility and wisdom. In demonstrating this dynamic, an exegesis of Mark 7:24-31 a will draw attention to its two chreias to illustrate that the woman's chreia has the last word in this repartee. Second, drawing on the virtue ethics of James Keenan some remarks will be offered on the virtue of humility: what it is and how wisdom is attained through its practice. Third, a virtue interpretation of Mark 7:24-31 a will show how both the Syrophoenician woman and Jesus serve as examples of humility and how their living out of that virtue leads to wisdom.

\footnotetext{
${ }^{1}$ Biblical translation used: (1) John R. Donahue \& Daniel J. Harrington, The Gospel of Mark, vol. 2 of Sacra Pagina (Collegeville, Minnesota: Liturgical Press, 2002), and (2) The Harper Collins Study Bible, New Revised Standard Version. Harold W. Attridge, General Editor (San Francisco: HarperOne Publishing, 2006).

* Christopher E. Alt holds a B.A. in theological and religious studies from the University of San Diego. He is a third-year M.Div. student in the School of Theology and Ministry at Boston College. His focus is in biblical and practical theology.
} 


\section{Introduction}

The encounter between the Syrophoenician woman and Jesus in Mark 7:24-31a goes largely unnoticed. However, this pericope is worthy of deep reflection and, as this paper will demonstrate, can lead to profound ethical insights. This text certainly recounts boundarybreaking activity and the power of God that can be accessed through faith. This paper, however, will explore how this story offers an example of the dynamic between the virtue of humility and wisdom. To do this, we must explore several pertinent questions: How is authentic humility manifested in the story? What are some defining features of wisdom? How do the characters discover it? What is wisdom's relation to humility? This story is about more than just the Syrophoenician woman winning the day. Rather, Mark offers readers a glimpse of a more fundamental truth. Therefore, the question is not whose story this is. Unlike some commentators who are content to quarrel over the question of which character is the protagonist, this paper does not take this either/or approach. It is as much about the Syrophoenician woman as it is about Jesus. Both individuals walk away changed, healed, and strengthened. Through this encounter, both practice humility, and thus, both discover wisdom; Jesus' provisional myopia is abrogated while the woman acquires a healing for her beloved daughter. Indeed, both of these characters walk away different - with expanded visions. By extension, their exchange also has implications for those not directly involved in the story: for the woman, her daughter gains freedom from the binding demonic forces; for Jesus, his thoughts concerning the ministry to the Gentiles will be expanded. Furthermore, like all "good news," the story remains effective, reaching even contemporary readers.

To be sure, readers will notice many unusual, anomalous, and jarring elements in this pericope. This is what makes it so intriguing and, at times, so frustrating. It begins like any other Markan healing story, but by the end, readers find it memorable for other reasons. ${ }^{2}$ Despite all of these points, it continues to be an underrated story. In his book A Costly Freedom, Brendan Byrne seems to lament the Church's exclusion of this text in the Sunday readings. The lack of awareness this text receives results in an underappreciation of its latent significance:

It is regrettable that the compilers of the Roman Catholic Lectionary did not see fit to include this episode (Mark 7:24-30), along with that of the Gerasene demoniac (5:1-20), among the Sunday Gospel readings for Year B - a misguided attempt, surely, to 'protect' the faithful from more challenging aspects of the Gospel. ${ }^{3}$

Regardless of this unfortunate omission, this story deserves greater consideration. This paper will show how this pericope offers readers insights on how to live out the virtue of humility and subsequently, how this virtue is related to wisdom. This discussion is divided into

\footnotetext{
${ }^{2}$ Donahue and Harrington outline the general pattern of a Markan healing story: (1) the arrival of the miracle work at the locale of the sick person; (2) a description of the illness or problem; (3) a request for healing, implicit or explicit; (4) the healing action either by gesture or by word; (5) the effecting of the mighty deed; and (6) acclamation by the crowd or some external demonstration of healing, The Gospel of Mark, 85 .

${ }^{3}$ Brendan Byrne, A Costly Freedom (Collegeville, Minnesota: Liturgical Press, 2008), fn. on 127.
} 
three parts: First, an exegesis of Mark 7:24-31a; second, an exploration on the virtue of humility - what it is and how wisdom is attained through its practice; and third, a virtue interpretation of Mark 7:24-31a, showing how both the Syrophoenician woman and Jesus serve as examples of humility and how the living out of that virtue leads to wisdom.

\section{Part I: Exegesis of Mark 7:24-31a}

The pericope of the Syrophoenician woman can be read as a unit given its clear beginning, middle, and end. It is best read within a larger context where it can be further illumined through an intra- and inter-biblical reading.

Daniel Harrington has exhorted students to read the Pauline epistles in the proper context, stating: "Context is (nearly) everything." ${ }^{4}$ This insight is important when reading all biblical texts, no less so when reading Mk 7:24-31a. The exorcism of the Syrophoenician woman's daughter "has the formal characteristics of both a miracle story and a controversy." 5 Thus it follows a specific literary pattern. The miracle does indeed take place at the end of the story, but it is what happens in between that makes the story so interesting. The "meat" of the passage has Jesus and the woman engage each other in a dialogue/banter/controversy regarding the appropriateness of Jesus' power and presence being extended beyond the Jewish community. ${ }^{6}$ In the larger context, it occurs near the latter stages of Jesus' activity around the Sea of Galilee. This passage is directly preceded by Jesus' dispute with the Pharisees over what constitutes clean and unclean food. Since Jewish dietary laws were considered one of their most important purity markers, Jesus' supposed pronouncement judging all food clean would have logically been "a warrant for acceptance of Gentiles." ${ }^{77}$ Mark 7:24-31a could have served several functions for the early Christian community (as well as today). One such function could be that it sets the precedent for including "outsiders" into the church. Furthermore, Mark continues to employ his motifs of food, eating, and bread, as well as the proper response and faith in this miracle/controversy passage.

Though these themes are indeed prominent in the story, this paper focuses on the underscoring dynamics that make these boundary-breaking activities possible. To briefly reiterate the purpose of this paper, I will make explicit the dynamics that undergird the transformation that results from each character's practice of humility, and derivatively, how the actions of the Syrophoenician woman and Jesus reveal the path to wisdom. I now propose the following outline (it will provide the springboard for the scriptural exegesis that will come immediately thereafter):

\footnotetext{
${ }^{4}$ Daniel J. Harrington, “Jesus, Paul, and Virtue Ethics” (lecture, Boston College, March 1, 2011).

${ }^{5}$ Donahue \& Harrington, The Gospel of Mark, 235.

${ }^{6}$ Ibid.

${ }^{7}$ Ibid.
} 
General outline for Mark 7:24-31 $a^{8}$

a. Jesus' arrival near Tyre and effort to escape notice (24)

b. The woman approaches (25)

(Paranthetical note on the woman's ethnicity [26a])

c. The woman's petition (26)

d. Jesus' response $(27)^{9}$

e. the woman's retort (28)

d'. Jesus' second response (29a)

$c^{\prime}$. The woman's petition is granted (29b)

b'. The woman returns home and finds her daughter healed (30)

$\mathrm{a}^{\prime}$. Jesus' return from the region of Tyre (31a)

\section{A. Mark 7:24: Jesus sets out for Tyre}

24. He then rose up, left that place, and set out on a journey to the region around Tyre. He went into a house and did not want anyone to know he was there, but it was impossible to avoid being discovered.

Mark indicates that Jesus entered a house, wishing to hide himself from the massive crowds that have been following him since the onset of his ministry. The reader gets the sense that Jesus needed some time alone for rest and reflection, away from the commotion of the crowds or perhaps to re-center himself after the bitter dispute that just occurred between him and the Pharisees in the preceding verses. Like Mark 6:30, Jesus' attempt at rejuvenation will be thwarted. It is in that passage that Jesus feeds the 5,000 instead of taking time for himself. Similarly in this pericope, Jesus "feeds" the woman despite his initial intention. Unlike Mk 6:34 however, Jesus does not respond compassionately to the Syrophoenician woman in need.

It is important to note where Jesus seeks isolation. It is in Gentile territory and is also a potentially dangerous place for him as a Jew. ${ }^{11}$ Tyre had a mixed population of Jews and nonJews; Mark's readers would have known these two groups to "be bitter enemies." ${ }^{12}$ This fact heightens the boundary-breaking drama that will ensue in the following passages. Not only are Jesus and the Syrophoenician woman "strangers," they belong to rival cultures/nationalities.

B. Mark 7:25-26: The woman approaches and petitions Jesus

\footnotetext{
${ }^{8}$ This outline is taken from Sharon Ringe's essay, "A Gentile Woman's Story, Revisited: Rereading Mark 7:2431A," in A Feminist Companion to Mark, eds. Amy-Jill Levine with Marianne Blickenstaff (Cleveland, OH: The Pilgrim Press, 2004), 82. It should be noted that the headlines in most bibles break at verse 30 . In this paper, however, verse 31 has been included so as to retain the chiasm.

9 "Jesus' response" in Mk 7:27 is a chreia, "a saying that conveys an example of the wit and wisdom of a philosopher or other famous person. It was a common form in Greek rhetoric and was often used as a teaching device in rhetorical schools," Ringe, "A Gentile Woman's Story, Revisited," 90. Typically, Jesus' chreia serves as the climax of any given passage. Here, however, the woman's retort, i.e., chreia, serves as climax of passage.

${ }^{11}$ Donahue \& Harrington, The Gospel of Mark, 232.

${ }^{12}$ Ibid.
} 
25. Right away upon hearing about him, a woman whose little daughter was possessed by an evil spirit came and threw herself down at his feet. 26. (But this woman was a Greek, a Syrophoenician by birth.) And she begged him to expel the demon from her daughter.

It seems that Mark conveys urgency in each action, regardless of the agent. This actionwith-urgency is captured once again in verse 25 . This is circumstantial evidence for the later argument that the woman's dialogical engagement with Jesus discussed in part $\mathrm{C}$ is not a "lighthearted" or "whimsical" repartee, but rather concerns a serious matter.

Mark tells us that the woman prostrates herself before speaking to Jesus (as contrasted with Matthew's Gospel which has her engage Jesus verbally before kneeling down at his feet). This demonstrates her proper greeting of someone who has the reputation of being a "Stronger One." ${ }^{13}$ Like the other successful supplicants, she recognizes her relation vis-à-vis Jesus. Also, unlike Matthew's Gospel, Jesus is curiously alone. This fact should not be overlooked. When read in the larger Gospel context where the disciples are virtually always present, it seems revealing. Jesus' sole interaction with the woman is one of the anomalies Mark presents to us. ${ }^{14}$

It is here that Mark offers background information on the woman who has approached Jesus. She is Greek (which identifies her religion, i.e., as a non-Jew) and a Syrophoenician (indicating her nationality). These two facts, along with her gender, make her thrice an "outsider." These "outsider" characteristics are noteworthy: it is as if Mark wants the readers to tally the characteristics that make the dicey forthcoming dialogue between her and Jesus all the more poignant.

Harrington and Donahue make another observation that could arguably lead to yet another disparity between Jesus and the woman. They argue that Mark's syntactical use of the word "gyne" could suggest something of the woman's social status. Literally, she was a Greek "lady." ${ }^{15}$ Thus, here is one more feature that sets this "lady" apart from the itinerant, presumably financially humble, Jesus. This also recalls Jairus, the Jewish man who disregards his Temple status and throws himself at Jesus' feet for a similar purpose. ${ }^{16}$

Finally, the impetus of the woman's supplication is stated. She explains that her daughter is demonically possessed and proceeds to "beg" for an exorcism. Up to and including this verse, the passage has followed the typical Markan healing pattern. It is in the following verses that the story takes a surprising turn.

\footnotetext{
${ }^{13}$ Mark's portrayal of Jesus as a wonder worker earns him the moniker of "Stronger One." Commentators have shown that Mark's Gospel sets Jesus' ministry within the context of a great battle between Jesus and the forces of evil. For more on this point, see Byrne pages xi-xii. Biblical examples include, for example, Mk 3:20-27, where Jesus is compared to the "Stronger One" who binds Satan and plunders his household.

${ }^{14}$ Donahue \& Harrington, The Gospel of Mark, 235.

${ }^{15}$ Ibid., 233.

${ }^{16}$ Mk. 5:22.
} 


\section{MARK 7:27-28: The controversy between Jesus and the woman}

27. But he said to her: "Let the children first eat all they want; for it is not right to take food from the children and throw it to the little dogs." 28. But the woman retorted and said to him: "Sir, even the little dogs under the table make a meal of the crumbs that the children give them."

Jesus' response is shockingly unexpected and could be interpreted in a variety of ways. "Children" refers to the Jewish people. ${ }^{17}$ The use of the word "first" could imply a sequential plan of action, i.e., Jesus seems to suggest that the "little dogs" (read: non-Jews) must at least wait their turn for food, if indeed, any will be given to them at all. ${ }^{18}$ Some commentaries try to assuage the readers' initial reaction by arguing that Jesus' reference to the woman and her nonJewish counterparts as "little dogs" is not so "offensive" given the context. The Oxford Bible Commentary, for example, proffers the possibilites that either, 1.) "little dogs" could be a household pet and therefore does not need to be thought of as distasteful, or 2.) perhaps Jesus was playing devil's advocate, intending to evoke a response from the woman. ${ }^{19}$ In the same vein, others may read this as Jesus initiating a sort of light-hearted repartee or banter with the woman, who responds to him in kind. Tom Wright takes this line of argument. ${ }^{20}$ It is the opinion here that these interpretations are inadequate in the light of inter-textual, socio-historical, and literary considerations.

In the Hebrew Scriptures and in other Christian writings, to call someone a "dog" was an insult. ${ }^{21}$ Presumably, the negative connotation attributed to "dogs" reflects the historically Jewish notion that such creatures were unclean - one with resonances even in contemporary society. To call someone a "dog/bitch" today is no less pejorative. Literarily speaking, the interpretation of this exchange as a "light-hearted repartee/banter" is not appropriate given the gravity of the situation. What mother is going to indulge in such conversation while her daughter is in a state of demonic possession? Furthermore, it also does not fit the "urgency" by which she approaches Jesus. Thus, it is the conclusion here that the reader's initial reaction is correct: Jesus' indignant response is unnecessarily harsh.

\footnotetext{
${ }^{17}$ Donahue \& Harrington, The Gospel of Mark, 233.

${ }^{18}$ The use of the word "first" does not necessarily mean that the "little dogs" will be given anything to eat. Byrne says, "The word 'first' leaves open the possibility that a time may come when others beyond 'the children' might also be fed. But the second statement, extending the image to include not only the children but also house dogs, seems harshly to close this off" (125-126). Hisako Kinukawa concludes that Jesus' original (historical?) answer lacked the "first" and would have sounded "very blunt to the woman." Hisako Kinukawa. Women and Jesus in Mark. A Japanese Feminist Perspective (Maryknoll, NY: Orbis Books, 1994), 56.

${ }_{19}$ C.M. Tuckett, "Mark," in The Oxford Bible Commentary, eds. John Barton and John Muddiman (Oxford, UK: Oxford University Press, 2001), 900. The Eerdman's Commentary on the Bible seems partial to this line of interpretation as well. See "Mark" in Eerdman's Commentary on the Bible, eds. James D. G. Dunn and John W. Rogerson (Cambridge, UK: Eerdmann's Publishing Company, 2003), 1081.

${ }^{20}$ N. T. Wright. Mark for Everyone, (London: Society for Promoting Christian Knowledge, 2001), 95.

${ }^{21}$ Donahue \& Harrington, The Gospel of Mark, 234 (cf. 1 Sam 17:43, 24:14; Isa 56:10-11; Prov 26:11; Matthew $7: 6)$.
} 
One should also recall the structure of the pericope. It may lend further clues for what Mark means to convey. Sharon Ringe argues that Mark's use of chiastic structure alludes to controversy stories found elsewhere in the gospel. Here, however, readers notice a striking difference. Jesus is the one who typically "bests" his interlocutors; his chreia(s) (a.k.a. "punch line") serves usually as the climax of the passage and is therefore presented as the superior point of view. As Ringe notes, "The woman's reply turns the story into a double chreia, with the punch line in the second half... Her retort wins the day. Her point of view prevails in the story and is eventually adopted by Jesus in 7:29."22

Jesus' response is also somewhat puzzling, given that it concerns food and eating. Taken in the immediate macro-context of Mark's gospel, one that is concerned with bread, food, and eating (i.e., symbolic of Jesus' teaching that "fulfills"), Jesus' response does not seem to conform to the woman's request. She is not asking to receive a satisfying teaching, but rather a healing - a completely different action. Nonetheless, the woman keeps with Jesus' metaphor and "bests" Jesus at his own word-play game. Again, given the more dramatic reading of this text, the word "retort" is a good translation. ${ }^{23}$ Using his own degrading metaphor, she boldly turns the tables on Jesus and causes him to reconsider his position. This unparalleled "besting" of Jesus, by a woman no less, is a revelatory experience for Jesus that causes him to reconsider his own ministerial mission. It is a key passage that compels Jesus to expand his teaching ministry to non-Jews. How appropriate that shortly hereafter Jesus is found "feeding" the 4,000 Gentiles. Thus, strangely enough, the woman teaches Jesus to remember what he has just exhorted others regarding what constitutes a person clean or unclean. She confronts Jesus and gives him the opportunity to practice what he has just preached. ${ }^{24}$

\section{Mark 7:29-31a: Jesus concedes and grants the healing}

29. And he said to her: Because of what you said, go home; the demon has already left your daughter." 30. When she arrived home, she found her little child lying on a bed, but the demon was gone. 31. And once again he set out from the region around Tyre and traveled by way of Sidon toward the Sea of Galilee through the region of the Decapolis.

Many bibles title this passage: "The Syrophoenician Woman's Faith." Ironically, Mark never mentions the woman's "faith." Matthew's parallel story will make the woman's faith an

\footnotetext{
22 Ringe, "A Gentile Woman's Story, Revisited," 90.

23 "The double verb "retorted" and "said" reflects a high rhetorical style, and is found elsewhere only on the lips of Pontius Pilate" (Donahue \& Harrington, The Gospel of Mark, 234). This lends further credence to the notion that the woman was a Greek "lady." For purpose of this paper, it is additional evidence of the status gap between her and Jesus. It also makes her prostrated supplication more poignant. Furthermore, it may make her retort all the more filled with humble indignation - she was a lady, not a "little dog." This last point may be impossible to adequately argue due to the impossibility of psychologizing any biblical character. We can never know if the woman, given her dire situation, would have wanted to retain some dignity or strip herself completely of status for the promotion of her daughter. Regardless, Donahue and Harrington argue that Jesus' use of the metaphor compares the woman (and implicitly the Greeks) with "dogs," i.e., unclean, degrading creatures.

24 This begs several Christological questions. These will be touched upon in Part III of this paper.
} 
explicit part of Jesus' final response to the woman. In this case, it is tacit. The readers realize that it is only after the woman's bold riposte-and even because of it-that Jesus capitulates and grants the healing.

\section{Part II: The Christian Virtue of Humility and its Relation to Wisdom}

In the two books Jesus and Virtue Ethics and Paul and Virtue Ethics, Harrington and James Keenan offer readers a fine introduction on humility, a virtue that they contend is distinctly Christian. ${ }^{25}$ Too often, people think of humility as having a modest or low view of one's own importance. In this mindset, it is taken as the opposite of pride. It also causes most people to assume incorrectly that humility is on the completely other end of the virtue-vice spectrum; they place it on the exact opposite pole from pride. People forget that virtues do not act as polar bookends to vices. This is to say that virtues, rightly understood, go against extremes. ${ }^{26}$ They are more the books in between the bookends, the white cream between the oreo cookies. These analogies, however banal, simply mean to illustrate the space virtues occupy. Again, virtues are not extremes, but rather the median between two corresponding vices (this explains why we get it wrong more than we get it right; the virtue is always outnumbered $2: 1){ }^{27}$

As already noted, within the context on a discussion about humility, pride occupies one extreme. The other-the one that is often confused with humility-is self-deprecation. Keenan describes this as an extreme that "[makes] oneself so weak as not to exercise oneself responsibly." ${ }^{28}$ Elsewhere, Keenan adds, "[w] hen we find our place between...extremes, we are humbled, for we shall stand before God. We are a people who hope and trust that we are savedsinners, but saved."29

Can we say anything further concerning the virtue of humility and how it is "thickened" by the Christian context? ${ }^{30}$ Keenan highlights Mary and her song of praise, the Magnificat (Lk 1:68-79), to illustrate his definition of the virtue and what it entails. Mary's song expresses humility because it is there that she identifies her place in the salvific and merciful plan of God. It is not considered a hymn of humility because she belittles herself or communicates excessive self-modesty in the face of the Lord. Rather, she offers a nuanced, balanced, and therefore correct location of her place in God's world. ${ }^{31}$ Conversely, then, we see it is the prideful or falsely humble person who is vicious, precisely because they fail to discern their place in the

\footnotetext{
${ }^{25}$ James Keenan, “Jesus, Paul, and Virtue Ethics” (lecture, Boston College, March 29, 2011). See also: Daniel J. Harrington, and James F. Keenan, Paul and Virtue Ethics (Chicago: Sheed \& Ward: 2002), 141.

${ }^{26}$ Daniel J. Harrington, and James F. Keenan, Jesus and Virtue Ethics (Lanham, Maryland: Littlefield Publishers, 2010), 191.

${ }^{27}$ Keenan, "Jesus, Paul, and Virtue Ethics" lecture.

${ }^{28}$ Harrington and Keenan, Jesus and Virtue Ethics, 192.

${ }^{29}$ Harrington and Keenan, Paul and Virtue Ethics, 143.

${ }^{30}$ Keenan argues that when one's virtue is directed to a particular end (i.e., telos), that end can be said to "thicken" one's understanding of that virtue. For example, Christian virtues are "thickened" (or "colored") by the Christian's ultimate end, the Kingdom of God ("Jesus, Paul, and Virtue Ethics" lecture).

${ }^{31}$ Harrington and Keenan, Paul and Virtue Ethics, 142.
} 
world and the community. Recall that Luke places this song on the lips of Mary right after she has been visited by the angel of the Lord who informs her of her place and mission as the mother of God. In the song, she not only sings of her own location in the world, but also addresses those who have erroneously staked their place in the universe. She also correctly sings of God's place, power, and presence in this earthly, divine-human dynamic. Keenan says, "To be humble is to know one's power in the universe and to respect one's own place in that universe and the place of others." ${ }^{32}$

Furthermore, Keenan argues that we can really only discern our place in the world through humility. This is because God in Christ has first shown how this is true through the mystery of the incarnation. Citing another New Testament hymn, Philippians 2:5-11, Keenan contends that God has shown his place in the world as the One for us; God humbles Godself by becoming human. Thus, God shows what kind of God he is, namely, the One who situates himself in our world, effectively sharing himself. This results in our redemption and own transformation through Jesus' death and resurrection. ${ }^{33}$

To bolster his argument on the virtue of humility, Keenan invokes Augustine. Contrary to the notion that humility is nothing more than "a strategy against pride," Augustine (similar to Paul, according to Keenan) views it as "a virtue of self-understanding, for knowing one's place in the community." ${ }^{34}$ Keenan argues that humility holds a pride of place (no pun intended) for Augustine: "the foundational stance of humility as the virtue for all Christians is found in Augustine." ${ }^{35}$ He writes in Letter 118:

I wish you would submit with sincere piety to Him and not seek any other way to abiding truth but the one shown us by Him who, being God, knows our weakness. This way consists, first, of humility, second, of humility, and third, of humility....It is not that there are no other precepts to be mentioned. But, unless humility precedes, accompanies, and follows whatever we do, unless it is a goal on which we keep our eye, a companion at our side, and a yoke upon our neck, we will find that we have done little good to rejoice in; pride will have bereft us of everything. ${ }^{36}$

In addition, Keenan cites Augustine's Tractate 5 on John 1:33. There Augustine proffers the notion that Jesus came to point out the way of humility. He himself, "is the way of humility." ${ }^{37}$ Keenan continues in this Augustinian key, citing Tractate 58:4 on John 13:10-15: "humility is learned from the Highest; let us, as humble, do to one another what He, the Highest, did in His Humility. ${ }^{38}$ Keenan rightly discerns Augustine's main point: as disciples of Christ, we are to be with him and to do what he does. In the immediate context, this means that we are disciples when we strive for humility, for that is the way of Christ. Thus, Keenan concludes that the traditional notion that sees humility as bending down is overemphasized, or at least, needs to

\footnotetext{
${ }^{32}$ Harrington and Keenan, Jesus and Virtue Ethics, 192.

${ }^{33}$ Harrington and Keenan, Paul and Virtue Ethics, 142-143.

${ }^{34}$ Ibid., 145.

${ }^{35}$ Ibid., 143.

${ }^{36}$ Augustine, "Letter 118", quoted in Harrington and Keenan, Paul and Virtue Ethics, 143. Emphasis mine.

${ }^{37}$ Augustine, "Tractate 5 on John 1:33", quoted in Harrington and Keenan, Paul and Virtue Ethics, 144.

${ }^{38}$ Augustine, "Tractate 58.4 on John 13:10-15", quoted in Harrington and Keenan, Paul and Virtue Ethics, 144.
} 
be nuanced: "Humility is really not about an ability to move but again, about knowing where you are. Humility, then, has special significance in the community. It has a communal feature, for if I know my place, I know it in relationship to others." 39

Although Keenan argues that is it less about movement and more about "knowing where you are," this implies that once one discerns through humility one's correct location in the world, they may have to move in order to acquire that correct location. This is to say, if one comes to recognize that he depends on God, but is currently living in a way that does not conform to this reality, it is his task to practice humility and thereby do what is necessary to situate himself in proper relationship. Thus, the virtue of humility as Keenan presents it needs some nuancing; if one is to grasp the full nature of virtuous humility, this dynamic mentioned above needs to be addressed. In addition to knowing where one is located, the person must also know who they are and who they are called to be, which may require a "movement." As Augustine says in his Tractate in John 25:16, "Human, know that you are human. Your whole humility is to know yourself." 40

Keenan's discussion on the contemporary emphasis of humility should also be noted. Here, Keenan draws upon the work of Margaret Farley. Farley, who is "concerned with the experience of authority and its afflictions, which often make a person unquestionably self-reliant and self-assured," proposes the notion of the "grace of self-doubt." ${ }^{41}$ Farley herself defines it as "epistemic humility, the basic condition for communal as well as individual moral discernment." It allows us to "throw off the 'albatross of certitude."' This epistemic humility can be defined as a

...grace for recognizing the contingencies of moral knowledge when we stretch toward the particular and the concrete. It allows us to listen to the experience of others, take seriously reason that are alternative to our own, rethink our own last word. It assumes a shared search for moral insight, and it promotes (though it does not guarantee) a shared conviction in the end. ${ }^{42}$

Practicing this kind of humility helps one to remove blinders and resist one's own self-righteous myopia. Expounding further on Farley's argument, Keenan states:

[It is this] form of humility [that] allows us to enter into discourse rather than to tower above it. By relinquishing the power of certitude, it discovers a new authority, an authority in which the admission of ignorance might actually be a way to truth. If truth is found, then, not by me but by us, then there must be certain virtues that aid us in our pursuit of truth. ${ }^{43}$

Thus, humility is foundational to our pursuit of truth (i.e., wisdom); wisdom is defined as such by its association with humility.

\footnotetext{
${ }^{39}$ Harrington and Keenan, Paul and Virtue Ethics, 146.

${ }^{40}$ Quoted in the article by Alvaro Huerga, "Humility" in Encyclopedia of Theology. The Concise Sacramentum Mundi, ed. Karl Rahner, (New York: Crossroad, 1982), 671.

${ }^{41}$ Margaret Farley, "Ethics, Ecclesiology, and the Grace of Self-Doubt," quoted in Harrington and Keenan, Paul and Virtue Ethics, 146.

${ }^{42}$ Ibid.

${ }^{43}$ Harrington and Keenan, Paul and Virtue Ethics, 146.
} 


\section{Part III: Virtue Interpretation of Mark 7:24-31a An Example of Wisdom Through Humility}

One could talk of the boundary-breaking activity that occurs in Mk 7:24-31, but here we are concerned with the practice of a particular virtue that makes this possible, namely humility. Recall that Keenan describes humility as the virtue where one finds one's place between extremes. When this is done one is humbled and he "stand[s] before God. We are a people who hope and trust that we are saved-sinners, but saved." 44 This description fits well with how the Syrophoenician woman approaches Jesus. Upon hearing that Jesus is in the area, she "immediately" runs to seek his aid. Her urgency demonstrates a disposition of trust and hope towards Jesus. Furthermore, her prostration shows deference to the man she believes can save her child. If the above analysis is correct that she was a Greek "lady," then she is one who disregards her class, national, and religious affiliations in order to supplicate before the "Stronger One." Indeed, regardless of whether she thinks that he is the Son of God or a mere miracle worker, she nevertheless approaches him in an appropriate manner-with humility. Indeed she has rightly located herself before "God."

Furthermore, this woman is the model of humility because she rightly discerns the median position between pride and self-deprecation. She does expect Jesus to help her, but as her prostration has shown, she, like Jarius in Mark 5:23-43, is respectfully asking for it. There is no hint of pride in her disposition, nor even in her witty riposte. Moreover, even though Jesus has dealt her a degrading blow in the hour of her greatest need and desperation, she refuses to reciprocate with hostility. Hisaku Kinukawa has made an interesting point in this regard: Contrasting it with how the Syrophoenician woman could have reacted, she says, "If any woman in a contemporary, individually oriented society were to hear such a response, she would become too angry even to remain there, preferring to endure her daughter's suffering rather than swallow such an affront." ${ }^{45}$ Perhaps this is true, but certainly the woman could have answered in a completely opposite way as well. Jesus' response could have caused her to cower in fear just as easily. Is it not also a common human reaction to shrink away in sadness, dread, and/or humiliation after being dismissed by someone held in high esteem-someone believed to have had authority to correct the situation? Rather, the woman finds the mean between pride and selfdeprecation; she is practicing humility in her initial approach and in her retort.

We now turn to the figure of Jesus. As already argued in Part I, Jesus' first response to the woman is unnecessarily harsh. However, he shows how he is the embodiment of wisdom by his own practice of humility. Jesus' second response-"because of what you have said"-demonstrates that he recognized the truth in her humble reply. Her action and response were the catalyst for his change of mind. Though it may sound inappropriate to claim that Jesus "discovers" something,

\footnotetext{
${ }^{44}$ Ibid., 143.

${ }^{45}$ Hisako Kinukawa, Women and Jesus in Mark (Maryknoll, NY: Orbis Books, 1994), 58.
} 
inter- and intra-biblical readings show precedence for this concept. Essays in systematic theology can also justify this notion. ${ }^{46}$

The Old Testament itself provides some precedence for this "discovery," as found specifically in the books of Genesis, Exodus and Numbers. In Genesis 18, Abraham essentially haggles with God over the span of ten verses regarding the destruction of Sodom and Gomorrah. Abraham boldly converses with God over the justice of the matter. Throughout the text, Abraham seems to remind God what kind of deity he is: "Far be it from you to do such a thing, to slay the righteous with the wicked, so that the righteous fare as the wicked! Far be that from you! Shall not the Judge of all the earth do what is just?" (Genesis 18:25, NRSV) Better examples may be found in Exodus and Numbers. Exodus 32 recounts the infamous "Golden Calf" scene. Here, in the face of God's fury and wrath, Moses intercedes on behalf of Israel:

But Moses implored the Lord is God, and said, "O Lord, why does your wrath burn hot against your people, whom you brought out of the land of Egypt with great power and with a mighty hand? Why should the Egyptians say, 'It was with evil intent that he brought them out to kill them in the mountains, and to consume them from the face of the earth?' Turn from you fierce wrath; change your mind and do not bring disaster on your people. Remember Abraham, Isaac, and Israel, your servants....And the Lord changed his mind about the disaster that he planned to bring on his people" (Exodus 32:11-14). ${ }^{47}$

Here, it is Moses who reminds God that the Israelites are God's people. Moses appeals to God's reputation and quotes his promise to Israel's ancestors. Moses is the mediator between the disobedient Israelites and the angry deity. This same scenario is repeated in the narratives of the "wandering in the wilderness" in Numbers $14 .{ }^{48}$ In both instances, Moses averts the crisis, essentially reminding God of who God is-i.e., merciful, forgiving, and compassionate. The Syrophoenician woman does the same thing. With humility, she intercedes in her attempt to change the mind of the Son of God. ${ }^{49}$ Similarly, we see that God also demonstrates

\footnotetext{
${ }^{46}$ For examples, see essays like Karl Rahner's "Christology within an Evolutionary Worldview" in Theological Investigations-5, trans. K-H Kruger (New York: Crossroad, 1983), 157-192, and "Dogmatic Reflections on the Knowledge and Self-Consciousness of Christ" in Theological Investigations 5, trans. K-H Kruger (New York: Crossroad, 1983), 193-215. One may also find helpful James Keenan's essay (currently unpublished) titled, "Natural Law Debates and Forces of Nature." There, among other things, Keenan explains the classicist and historical approach concerning the quest for "truth." Classicists may find it difficult to accept that Jesus needed to undergo the same experiences as we do in order to understand his mission and who he was. Historicists on the other hand, find that the world and truth are constantly emerging; it can be said that truth is "discovered" in history by historical persons, including Jesus. Jesus, being fully God and fully human, was subject to evolutions in thought and needed to undergo processes of coming to greater self-consciousness just like every other human being. Thus, to maintain that Jesus as "God" was omniscient and therefore could not have possibly "learned" things is biblically unwarranted and doctrinally unnecessary. For yet further reading on this topic, see Aaron Pidel's essay, "The Consciousness and Human Knowledge of Christ According to Lonergan and Balthasar," in Lumen et Vita 1:1 (2011), http://ejournals.

bc.edu/ojs/index.php/lumenetvita/article/view/1699 (July 2012).

${ }^{47}$ Emphasis mine.

${ }^{48}$ Michael D. Coogan, The Old Testament: A Historical and Literary Introduction to the Hebrew Scriptures, $2^{\text {nd }}$ ed. (Oxford University Press, 2011), 139.

${ }^{49}$ Here, I am trying to argue against Tom Wright and others who claim, against a "feminist agenda," that Jesus' response to the woman was really just "teasing banter," and therefore not an actual alteration of mindset (cf. Wright, Mark for Everyone, 95).
} 
humility. God "recalls," so to speak his place and relationship with the world. God in the Old Testament, and "God" in Mark 7:29 (i.e., Jesus) changes his mind. This is to say that the mediators in the story caused them to "move," so to speak (again, think: location). Thus, Augustine's line in Tractate on John 25:16 can be adapted in this way: "[God], know that you are [God]. Your whole humility is to know [Y]ourself."

Finally, we must say something of the "epistemic humility" practiced, not only by the Syrophoenician woman, but by Jesus as well. Jesus confirms that he is wisdom incarnate, the "path of humility," not in spite of his being bested, but precisely because of his willingness to "listen to the experiences of others, take seriously reasons that are alternative to [his] own, and rethink [his] last word." ${ }^{50}$ Jesus is not the proud deity that constantly towers over the dialogue, but, as Augustine says, he is the path of humility that, at least in this instance, paradoxically "relinquishes the power of certitude" and thereby discovers a new authority. Jesus shows that the truly wise person recognizes when his/her position may require expanding and adapting. The wise person is not obstinate, declaring that it is only " $I$ " who know the truth. Rather, he shows that wisdom is found by $u s$, in history. In her essay, "The Syrophoenician Woman: A South Asian Feminist Perspective," Ranjini Wickramaratne Rebera puts finding truth through humility in terms of mutual ministry:

Although each of them challenged the other, the challenge was done with intentions of trying to establish understanding of each other's positions. It was not for the purpose of controlling the other. The outcome to the encounter was positive because both were able to place their different identities side by side and not as opposing forces. They worked toward the goal of being able to relate to each other rather than to dominate each other. They experienced power with each other. The woman gave Jesus the power to recognize his ministry to the Gentile people. Jesus gave her the power of life by healing her daughter. There is a mutual ministry in this encounter that is often lost in its focus on what is clean and what is unclean. ${ }^{51}$

Thus, both parties show how the virtue of humility is the foundation for discovering life, authentic power, renewed missions, expanded visions, and, in a word, wisdom. Augustine was correct: humility is the way of Christ; and since Christ is wisdom, humility is the foundation and way of wisdom.

\section{Conclusion}

Keenan illustrated the virtue of humility by focusing on Mary's Magnificat. Here, this paper has shown how the story of the Syrophoenician woman and Jesus is also an example of

\footnotetext{
${ }^{50}$ Margaret Farley, "Ethics, Ecclesiology, and the Grace of Self-Doubt," in A Call to Fidelity: On the Moral Theology of Charles E. Curran, eds. James J. Walter, Timothy E. O'Connell, and Thomas A. Shannon (Washington, DC: Georgetown University Press, 2002), 69. As the reader will have noticed by now, I am presuming that Jesus is the wisdom of God incarnate. For current discussions regarding a retrieval of Jesus as such, see Elisabeth Schüssler Fiorenza's Jesus: Miriam's Child, Sophia's Prophet, and Elizabeth Johnson's She Who Is.

${ }^{51}$ Ranjini Wickramaratne Rebera, "The Syropoenician Woman: A South Asian Feminist Perspective," in A Feminist Companion to Mark, ed. Amy-Jill Levine with Marianne Blickenstaff (Cleveland: The Pilgrim Press, 2004), 108.
} 
humility. Exegesis of the text reveals that boundary-breaking activity occurs. The virtue interpretation reveals the virtue practiced that makes this activity possible. Both the Syrophoenician woman and Jesus illustrate what the virtue of humility looks like (and sounds like, so to speak). This is to say, they illustrate how humility is manifested. Furthermore, this paper has explored some of the features of wisdom. Jesus provides an excellent example in this regard. Exercising "epistemic humility," he teaches that true wisdom listens, and at times adapts to meet particular situations.

Indeed, both characters discover wisdom through their practice of humility. Had either character exhibited prideful or self-deprecating tendencies, the engagment would not have led to their flourishing. In addition, the Syrophoenician woman and Jesus were humble, recognizing their place in the universe. The woman's approach and riposte demonstrated her humility (as the one at the feet of Jesus, trusting through faith), and Jesus' second response demonstrated his humility, too (as the compassionate one whose mission needed extending). In the end, Jesus is revealed as wisdom incarnate, whose way is humility. As disciples, Christians today are to follow this way. Since Christ is wisdom, and his way is humility, humility is the path to wisdom. 